\title{
FLAMMABILITY OF AN AZEOTROPIC MIXTURE OF ETHER AND FLUOTHANE WHEN VAPORIZED IN OXYGEN OR AIR ${ }^{1}$.
}

\author{
G. K. BRown ${ }^{2}$
}

AN ANAESTHETIC consisting of an azeotropic mixture of ether and Fluothane has been developed in Canada with hopes that it will not be explosive in the concentrations used during anaesthesia procedures. In this respect it is important to know whether the vapour of the anaesthetic is flammable when mixed with oxygen or air and, if so, what the range of flammability is.

As the result of a request received in the summer of 1959 from Dr. Gordon M. Wyant, F.F.A.R.C.S., Professor of Anaesthesia, University Hospital, University of Saskatchewan, Saskatoon, Sask., the Mines Branch of the Department of Mines and Technical Suryeys, at Ottawa, ágreed to prepare apparatus and perform tests in its electric equipment certification laboratories to determine the flammability lintrits of a sample of the azeotropic mixture of ether and Fluothane prepared by the manufacturing pharmacy of the University of Saskatchewan.

The flammability limits are not constants but are related to a number of factors connected with the experimental methods of making the determination. Some of these factors are: direction of flame propagation, size and shape of the confining vessel, initial temperature and pressure, turbulence, and source of ignition.

A study of available literature indicates that the lowest lower limit can be obtained with upward propagation of the flame; that normal variations of temperature, atmospheric pressure, and humidity do not have a great effect on the lower limit; that the igniting source should be strong enough to ensure ignition; and that the confining vessel should be long enough that true propagation can be differentiated from local combustion near the ignition source. In tests with tubes $(1,2)$, the lower limit falls and the upper limit rises as the tube diameter increases, but an increase in diameter beyond about $5 \mathrm{~cm}$. generally has little effect on the limit values.

From a safety point of vièw the method which will give the widest flammable range is considered the best one to use.

\section{DetaIls of Investigation}

The apparatus used is illustrated in Figures 1 and 2. It is essentially the same as apparatus used by the United States Bureau of Mines and described in its

Her Majesty the Queen, In Right of Canada, reserves the right to reprint this article.

'Prepared for publication in the Canadian Anaesthetists' Sociely Journal, July, 1960, by permission of the Director, Mines Branch, Department of Mines and Technical Surveys, Ottawa, Canada.

${ }^{2}$ Certification Officer, Fuels and Mining Practice Division, Mines Branch, Department of Mines and Technical Surveys, Ottawa, Canada:

SourCE: Internal Report FMP-60/13-EEC (E.E.C. No. 27), Jan. 28, 1960

Can. Anaes. Soc. J., vol. 7, no. 3, July, 1960 


$$
\text { A }
$$


G. K. BROWN: FLAMMABILITY OF AZEOTROPIC FLUOTHANE-ETHER

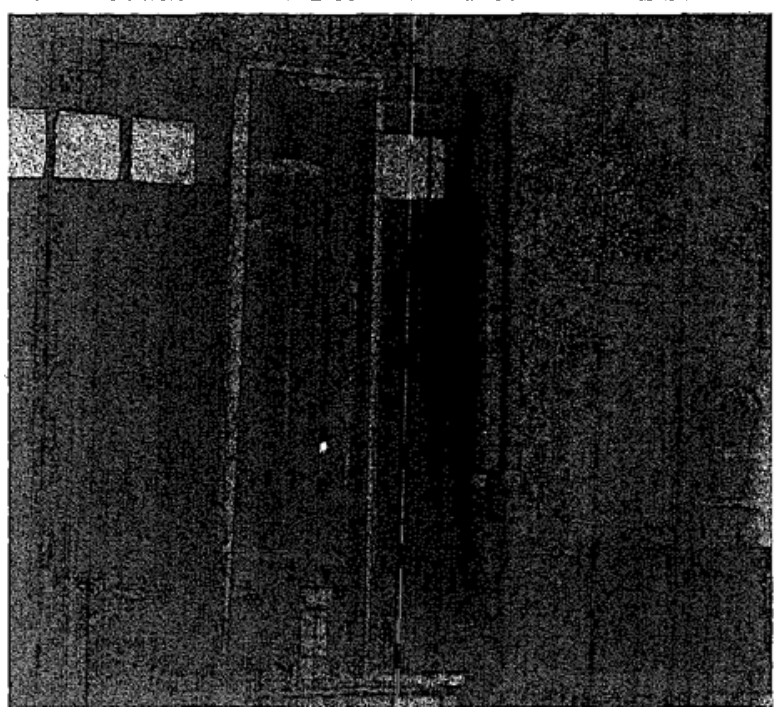

FigUre 2. Photograph of apparatus,

Bulletin 503, "Limits of Flammability of Gases and Vapors," except that drying tubes were dispensed with and an over-all enclosure with heaters and fan was provided so that tests could be performed at elevated temperatures.

The principal component of the apparatus consisted of a vertical glass tube $5 \mathrm{ft}$. long and $2 \mathrm{in}$. in diameter. Mixtures were prepared in this tube by the partial pressure method; that is, the system was evacuated, anaesthetic vapour was admitted to provide the desired percentage of atmospheric pressure, and oxygen or air was admitted to bring the pressure inside the system back to atmospheric. The mixture was then circulated by means of a pump consisting of a mercury vessel and a one-way valve. Raising and lowering the level of the mercury drew mixture from the top of the tube and pushed mixture in at the bottom. It was found that about twenty cycles of the pump were necessary to ensure

Figure 1. Diagram of apparatus

a. Glass tube, 2 in. diar, 5 ft. long

b. Ignition electrodes

c. Ground glass dis

d. Mercury seal

e. Mercury pump

f. 1-way valve

g. Manometer scale

h. Test sample

j. Liquid seal

mi. 3-way valve

for vacuum pump, oxygen or air

p. Enclosing chamber 
proper mixing. During the preparation of the mixtures a ground glass discl and a mercúry seal covered the bottom of the tube. This disc and seal were removed just before attempting ignition. The ignition source was a spark gap $\frac{1}{4}$ in. long, located 3 in. from the bottom of the tube. The sparking was produced by a General Electric ignition transformer, 250 volt-amperes, 10,000 volts secondary.

Tests were conducted at elevated temperatures to determine the upper limit, and at both elevated and room temperatures to determine the lower limit. This work was performed over a period of six weeks and has been grouped into five series of tests.

\section{Preliminary Tests}

The object was to check experimental procedures while determining the lower flammability limit of a liquid composed of 68.3 per cent Fluothane and 31.7 per cent ether (by volume), when vaporized in oxygen. It was also desired to determine, in particular, the effect of doing the tests at room temperature.

TABLE I

Results, Series 1

\begin{tabular}{ccccccc}
\hline Test no. & $\begin{array}{c}\text { Pressure } \\
(\mathrm{mm} . \mathrm{Hg})\end{array}$ & $\begin{array}{c}\text { Temp. } \\
\left({ }^{\circ} \mathrm{F} .\right)\end{array}$ & $\begin{array}{c}\text { Pump } \\
\text { cycles }\end{array}$ & $\begin{array}{c}\text { Percentage } \\
\text { mixture }\end{array}$ & $\begin{array}{c}\text { Flame } \\
\text { propagation }\end{array}$ & Remarks \\
\hline 1 & 761.5 & 80 & 20 & 11.1 & Yes & Loud noise \\
2 & 761.5 & 78 & None & 10.0 & No & \\
3 & 761.5 & 80 & None & 9.7 & No & \\
4 & 761.5 & 80 & None & 10.5 & Partial & $1 / 3$ up tube \\
5 & 761.0 & 80 & 20 & 10.5 & Yes & Loud noise \\
6 & 759.5 & 79 & 20 & 10.0 & Yes & Loud noise \\
7 & 759.0 & 79 & 20 & 9.0 & Yes & Loud noise \\
8 & 759.0 & 79 & 20 & 7.0 & No & \\
9 & 759.0 & 79 & 20 & 7.6 & Yes & \\
10 & 753.0 & 79 & 20 & 7.3 & No & \\
11 & 753.0 & 80 & 20 & 7.4 & Yes & \\
12 & 752.0 & 79 & 7 & 7.5 & Partial & $3 / 4$ up tube \\
\hline
\end{tabular}

One of the first observations as a result of these tests was that proper mixing was necessary: The lack of propagation or the partial propagation of flame in tests $2,3,4$, and 12 is attributed to poor mixing.

Another important observation was that pressure increased above atmospheric in the system as the pumping cycles proceeded. This pressure increase was in the order of $30 \mathrm{~mm} . \mathrm{Hg}$. An infrared spectral examination was carried out which indicated that no chemical reaction had taken place. It was therefore concluded that the increase of pressure was due to re-evaporation of a small amount of the anaesthetic vapour which had condensed as the oxygen was added to the system. This resulted in a little too much oxygen, but the error was largely compensated for by the fact that the mercury tube for measuring the degree of vacuum had not been tapped after evacuating the system. It was found that tapping the tube resulted in the mercury shifting, usually about an additional $2 \mathrm{~mm}$. 
As a result of the observations made during these preliminary tests a more accurate procedure was established for subsequent tests carried out at room temperature. When the oxygen was admitted it was shut off before the pressure in the system reached atmospheric, usually at about $75 \mathrm{~mm}$. $\mathrm{Hg}$ of vacuum. After the small amount of condensed vapour had evaporated again, the oxygen necessary to bring the system to atmospheric pressure was added.

In tests at elevated temperature this procedure was not necessary as no condensation occurred.

\section{Lower Limit Tests in Oxygen at Room Temperature}

TABLE II

Results, Series 2: Anaesthetic- $68.3 \%$ Fluothane and $31.7 \%$ Ether, by Volume

\begin{tabular}{ccccccc}
\hline Test no. & $\begin{array}{c}\text { Pressure } \\
(\mathrm{mm} . \mathrm{Hg})\end{array}$ & $\begin{array}{c}\text { Temp. } \\
\left({ }^{\circ} \mathrm{F} .\right)\end{array}$ & $\begin{array}{c}\text { Pump } \\
\text { cycles }\end{array}$ & $\begin{array}{c}\text { Percentage } \\
\text { mixture }\end{array}$ & $\begin{array}{c}\text { Flame } \\
\text { propagation }\end{array}$ & Remarks \\
\hline 13 & 762.5 & 76 & 20 & 7.35 & No & \\
14 & 747.0 & 80 & 20 & 7.65 & No & \\
15 & 741.0 & 80 & 30 & 7.8 & Yes & \\
16 & 741.0 & 79 & 25 & 7.7 & Yo & \\
21 & 759.5 & 79 & 25 & 7.7 & Yes & \\
22 & 757.0 & 79 & 25 & 7.55 & Yes & Tube black \\
23 & 766.0 & 78 & 25 & 7.41 & Yes & Tube black \\
24 & 765.5 & 79 & 25 & 7.32 & Yes & Tube black \\
25 & 765.0 & 78 & 25 & 7.3 & Yes & Tube black \\
26 & 763.5 & 80 & 25 & 7.2 & No & Tube black \\
\hline
\end{tabular}

Tests 17,18 , and 19 were conducted at elevated temperatures and comprise Series 3 .

It is considered possible that differences in barometric pressure may have some effect on the lower limit and may account for there being no propagation of flame in tests 14 and 16. If this is so, it would appear that higher barometric pressures tend to produce a lower limit.

Tests 22 to 26 were carried out after tests to determine the upper flammability limit, during which heavy black smoke was produced when flame propagation occurred. This accounts for the remark that the tube was black in tests 22 to 26. It is believed that if this darkening of the glass surface had any effect it would be to lower slightly the lower limit.

Lower Limit Tests in Oxygen at Elevated Temperature

TABLE III

Results, Series 3: Anaesthetic-68.3\% Fluothane and $31.7 \%$ Ether, by Volume

\begin{tabular}{cccccc}
\hline \hline Test no. & $\begin{array}{c}\text { Pressure } \\
(\mathrm{mm} . \mathrm{Hg})\end{array}$ & $\begin{array}{c}\text { Temp. } \\
\left({ }^{\circ} \mathrm{F} .\right)\end{array}$ & Pump cycles & $\begin{array}{c}\text { Percentage } \\
\text { mixture }\end{array}$ & $\begin{array}{c}\text { Flame } \\
\text { propagation }\end{array}$ \\
\hline 17 & 762.0 & 131 & 25 & 7.48 & Yes \\
18 & 762.0 & 131 & 25 & 7.35 & No \\
19 & 762.0 & 131 & 25 & 7.4 & Yes \\
\hline
\end{tabular}




\section{Upper Limit Tests in Oxygen at Elevated Temperature}

TABLE IV

Results, Series 4: Anaesthetic-68.3\% Fluothane and $31.7 \%$ Ether, by Volume

\begin{tabular}{cccccc}
\hline Test no. & $\begin{array}{c}\text { Pressure, } \\
\text { (mm. Hg) }\end{array}$ & $\begin{array}{c}\text { Temp. range, } \\
\left({ }^{\circ} \mathrm{F} .\right)\end{array}$ & $\begin{array}{c}\text { Pump cycles } \\
\text { Pmixture }\end{array}$ & $\begin{array}{c}\text { Percentage } \\
\text { miame } \\
\text { propagation }\end{array}$ \\
\hline 1 & 748.0 & 156 to 160 & 25 & 67.3 & No \\
2 & 746.0 & 176 to 165 & 25 & 53.0 & Yes \\
3 & 748.5 & 167 to 161 & 25 & 60.0 & Yes \\
4 & 761.5 & 156 to 171 & 25 & 64.0 & Yes \\
5 & 7620 & 149 to 173 & 25 & 66.8 & Yes \\
6 & 764.0 & 158 to 194 & 25 & 68.0 & No \\
\hline
\end{tabular}

Flammability Tests in Air

A preliminary test was made which consisted of boiling $10 \mathrm{ml}$. of the anaesthetic in a glass beaker 2 in. in diameter. Matches were lighted and held in various positions in the vapour and it would not catch fire. There was a very small space, in which position the match flame increased a little in size and at the same time a black smoke was produced.

TABLE V

Results, Series 5: Anaesthetic-68.3\% Fluothane and $31.7 \%$ Ether, By Volume

\begin{tabular}{ccccccc}
\hline \hline Test no. & $\begin{array}{c}\text { Pressure } \\
(\mathrm{mm} . \mathrm{Hg})\end{array}$ & $\begin{array}{c}\text { Temp. } \\
\left({ }^{\circ} \mathrm{F} .\right)\end{array}$ & $\begin{array}{c}\text { Pump } \\
\text { cycles }\end{array}$ & $\begin{array}{c}\text { Percentage } \\
\text { mixture }\end{array}$ & $\begin{array}{c}\text { Flame } \\
\text { propagation }\end{array}$ & $\begin{array}{c}\text { Approximate } \\
\text { flame length } \\
\text { (in.) }\end{array}$ \\
\hline 1 & 763.0 & 72 & 30 & 7.1 & No & 0 \\
2 & 760.0 & 75 & 30 & 9.75 & No & $\frac{1}{4}$ \\
3 & 756.0 & 79 & 30 & 11.0 & No & $1^{\frac{1}{2}}$ \\
4 & 763.0 & 77 & 27 & 11.4 & No & $2^{\frac{1}{2}}$ \\
5 & 763.0 & 80 & 40 & 12.0 & No & 3 \\
6 & 764.0 & 79 & 60 & 15.0 & No & 3 or 4 \\
7 & 763.0 & 79 & 50 & 20.0 & No & $2^{\frac{1}{2}}$ \\
$8^{*}$ & 754.5 & 80 & 20 & 33.0 & No & 2 \\
9 & 767.5 & 140 to 149 & 30 & 18.0 & No & 1 \\
10 & 769.0 & 140 to 167 & 25 & 23.3 & No & 1 \\
\hline
\end{tabular}

*Test 8 was for a saturated mixture at room temperature.

\section{Conclusions}

The lowest percentage mixtures with oxygen which propagated flame for the three series of tests concerned with the lower flammability limit were 7.4, 7.3, and 7.4, and the lower limit was chosen as the average between the lowest percentage which propagated flame and the next lowest which did not. This resulted in a lower limit in oxygen of 7.25 per cent. Similarly the upper limit in oxygen was 67 per cent.

From the results of the tests with the anaesthetic and air, it was concluded that there is unlikely to be a percentage mixture which will propagate flame in air and that for practical purposes the azeotropic mixture can be considered nonflammable in air. 


\section{SUMMARY}

Five series of tests-four in oxygen and one in air-were made with an azeotropic mixture received from the University Hospital, University of Saskatchewan, Saskatoon. This sample was labelled 68.3 per cent. Fluothane and 31.7 per cent ether by volume. Flame propagation was upward in a glass tube $2 \mathrm{in}$. in diameter and $5 \mathrm{ft}$. long, open at the bottom. The ignition source was the spark produced by a 250 va. General Electric ignition transformer, 10,000 volts secondary. All the tests to determine the upper limit of flammability in oxygen were at elevated temperatures and some of the tests to determine the lower limit were at elevated temperatures. The results in oxygen were lower limit, 7.25 per cent; upper limit 67.0 per cent. Tests indicated that the azeotropic mixture vaporized in air will not propagate flames and that the liquid has no flash point.

\section{ACKNOWLEDGMENTS}

Helpful discussions were had with Dr. D. S. Montgomery and Mr. R. G. Draper, senior scientific officers of the Fuels and Mining Practice Division. Miss Frances E. Goodspeed, aTso of the Fuels and Mining Practice Division, made the infrared spectral examinations.

\section{RÉSUMÉ}

Nous avons fait cinq séries d'expériences-quatre avec de l'oxygène et une avec de l'air-avec un mélange azéotropique reçu de l'hôpital universitaire, Université de Saskatchewan, Saskatoon. Cet échantillon était étiqueté $68.3 \%$ de Fluothane et $31.7 \%$ d'éther en volume. La propagation de la flamme se faisait de bas en haut à travers un tube de verre de deux pouces de diamètre et de cinq pieds de long; le tube était ouvert à son extrémité inférieure. La source d'allumage était une étincelle produite par un transformateur Greneral Electrique de 250 watts et 10,000 volts. Toutes les expériences pour préciser la limite supérieure d'inflammabilité dans l'oxygène se faisaient à des températures élevées et quelques-unes des expériences pour préciser la limite inférieure étaient également pratiquées à des températures élevées. Voici les résultats dans l'oxygène: limite inférieure, $7.25 \%$; limite supérieure, $67.0 \%$. Ces expériences nous permettent d'affirmer que le mélange azeotropique vaporisé dans l'air n'entretient pas les flammes que le liquide n'a pas de point d'explosion.

\section{REFERENCES}

1. Coward, H. F., \& Jones, G. W. Limits of Flammability of Gases and Vapors. U.S. Burealu of Mines Bull. 503, 155 pp. (1952).

2. Matson, A. F., \& Dufour, R. E. The Lower Limit of Flammability and the Autogenous Ignition Temperature of Certain Common Solvent Vapors Encountered in Ovens. Bulletin of Research no. 43, Underwriters' Laboratories, Inc., Chicago, IIl. (Jan., 1950). 